Vol. 6, No. 1, 2020

Lidia Bohun ${ }^{1}$, Eduard Pleshakov ${ }^{2}$, Sergiy Shvachko ${ }^{3}$

1. Department of Applied Materials Science and Materials Engineering, Lviv Polytechnic National University, Ukraine, Lviv, S. Bandery Street 12, E-mail: lidabohun@gmail.com, ORCID 0000-0002-3077-7756

2. Department of Applied Materials Science and Materials Engineering, Lviv Polytechnic National University, Ukraine, Lviv, S. Bandery Street 12, E-mail: ed.matchak@gmail.com, ORCID 0000-0002-2229-2820

3. Department of Applied Materials Science and Materials Engineering, Lviv Polytechnic National University, Ukraine, Lviv, S. Bandery Street 12, E-mail: shvsg0984903405@gmail.com, ORCID 0000-0003-2825-9519

\title{
FAILURE ANALYSIS OF A MOTOR VEHICLE SUSPENSION HELICAL SPRING
}

Received: May 07, 2020 / Revised: July 25, 2020 / Accepted: July 31, 2020

(C) Bohun L., Pleshakov E., Shvachko S., 2020

\begin{abstract}
The purpose of this work is to reveal the cause of the failure of the motor vehicle rear suspension barrel-shaped spring with the progressive elasticity characteristic and predict measures to increase the lifetime of springs of this type. The fracture of the spring occurred on the middle coil, which operates under conditions of more severe stress in comparison with other coils. The chemical composition of the spring material, determined by X-ray fluorescence spectral and microstructural analyzes, corresponded to chromium-silicon steel 54SiCr6. In terms of structure and mechanical properties, the spring material met the standards. No traces of decarburization were detected, and no crack initiation, caused by non-metallic inclusions, was found in the material of the fractured spring. Macroscopic examination of the spring surface did not reveal any cracks, scratches, dents, traces of blows with stones and marks of spring coiling tool. Instead, extensive areas of exfoliation of the protective coating were found. The metallographic analysis revealed selective corrosion in the form of pitting damage in places of exfoliation of the protective coating. The fatigue crack propagates from the certain deep pit with the reorientation of the crack plane along the spiral surface to the central axis of the coil wire. After depletion of the safety margin, the spring broke down quickly. The fast fracture zone contains steps of the river pattern formed due to the spiral reorientation of the fracture surface. The research can be used to understand the importance of adhesive strength and wear resistance of protective coatings on the spring surface. Their local exfoliation causes subsequent corrosion damage to the spring, which stimulates its fatigue fracture.
\end{abstract}

Keywords: barrel-shaped spring, spring steel, fracture, microstructure analysis, failure analysis, corrosion fatigue.

\section{Introduction and problem statement}

Automation and robotization of industrial and technological processes in different branches of human activity is a leading and long-term trend of development of modern society [1]. Nowadays, industrial robots have become quite widespread and have formed the main technological base of the machine-building, instrument-making, electrical and electronic fields of the world's industry [1], [2].

The suspension system is one of the vital components of the car, which guarantees traffic safety. Important elements of the suspension are springs and shock absorbers which absorb the energy of blows from roughness of a road surface, provide safe and comfortable driving of passengers without noise, blows, vibrations, increase lifetime of other systems of the car. The suspension springs hold the weight of the car while maintaining the required ground clearance, provide a reliable grip of the tires on the road.

The implementation of a constant trend in the modern automotive industry - reducing the weight of cars - also applies to steel suspension springs. Reducing their weight requires the use of steels with greater 
strength, elasticity, and relaxation resistance. However, increasing the strength of steel reduces its margin of ductility, which must be offset by the higher quality metallurgical production and technological processing of steel.

\section{Analysis of modern information sources on the theme of the paper}

Ensuring the reliable and safe operation of vehicles requires constant improvement of suspension systems, materials, etc. To do this, a lot of research work is being done in various directions, in particular, to determine the influence of various factors on the damageability of the suspension springs.

Loss of spring stiffness causes their subsidence, which increases vibration, shaking, body skew, reduces ground clearance, and damages the surface layer of coils due to the formation of traces and recesses from mutual impacts of adjacent coils [1]. This can have accidental consequences. In the work [2], the factors influencing the loss of spring stiffness and their subsidence are considered.

Paper of Prawoto et al. [3] fundamentally analyzes the stress distribution in the suspension springs, the characteristics of elastic materials, and the technology of manufacturing springs. Premature failure of the suspension springs is caused by metallurgical and technological defects (non-metallic inclusions, decarburization of steel, etc.), defects of the spring surface that create stress concentration, weakening of the cross-section of the springs due to corrosion. Studies [4] confirm that metallurgical factors, such as non-metallic inclusions, decarburization, internal cracks, cavities, corrosion are the main factors of premature failure of the suspension components.

Corrosion is a common cause of suspension springs degradation. It causes a weakening of their mechanical properties and a decrease in the ultimate life [5]. Corrosive damage caused by the external environment begins on the surface of the springs and, spreading over time, can be the root cause of fatigue fracture.

The nucleation of fatigue cracks begins on the surface of the springs in weakened areas or places of stress concentration. An important role is also played by the stress state of the surface layer: the residual compressive stresses counteract the nucleation and growth of fatigue cracks and, conversely, tensile stresses, arising, for example, due to decarburization, stimulate the development of fatigue. In particular, the influence of residual stresses on the resistance of steels to corrosion failure is considered in the work [6]. To increase the fatigue life of steel springs, Harada et al. [7] recommend microshot peening, which generates favorable compressive stresses in the surface layers of the springs.

The authors of the study [8], based on the failure analysis of the tension spring, recommend stress relieving operations, reducing surface irregularities, such as pits and cracks.

It is noted [9], [10], [11] that helical coil springs are more often fractured in the zone of transition from the reference to the first active coil for various reasons, in particular, due to the collection of a corrosive environment in a narrow space between the adjacent coils [11].

A number of researchers [11], [12] found that the fracture of the springs with a protective coating investigated by them occurred due to corrosion fatigue. The places of the nucleation of fatigue cracks were the areas of fracture of the polymer-based paint layer under the influence of impact closure of adjacent coils. Unprotected areas were damaged by pitting corrosion, and the fatigue fracture of the spring started from them.

Fragoudakis et al. [13] on the example of the $56 \mathrm{SiCr} 7$ spring steel demonstrate a significant increase in the lifetime of springs by optimal heat treatment.

\section{Aim and task of the investigation}

Investigation and analysis of the causes of failure of the safety-critical springs of the vehicle suspension do not stop due to the continuous renewal of spring designs, improvement of spring materials, and changes in operating conditions. This requires further analysis of various cases of a spring failure, which can be used by manufacturers to develop measures to improve their quality and reliability. Therefore, the purpose of this work is to reveal the cause of the failure of the coiled helical spring of the 


\section{Lidia Bohun, Eduard Pleshakov, Sergiy Shvachko}

rear suspension of the Ford Fiesta car and predict measures to increase the lifetime of springs of this type. This spring belongs to the group of springs with progressive elasticity characteristics: it is barrel-shaped and has a longitudinal variable pitch. In a static condition of the car suspension, all coils of the spring are loaded and provide the certain stiffness of the spring. As the load increases, the coils with a smaller step close, the number of active coils decreases, and the spring stiffness increases. Coiled springs of suspensions are springs of repeated dynamic action and are intended for holding axial compressive cyclic loadings [14].

The investigated spring of the rear suspension had fractured after 210 thousand $\mathrm{km}$ of run of the car.

\section{Experimental procedure and results}

The fractured spring has the form of a barrel-shaped helix coiled to the right (Fig. 1, a). The outside maximum diameter of the spring is $108 \mathrm{~mm}$, the minimum diameter is $76 \mathrm{~mm}$, the total height of the unloaded spring is $336 \mathrm{~mm}$. The total number of spring coils is 7 and the spring wire diameter is $10 \mathrm{~mm}$. The spring weight is $1.25 \mathrm{~kg}$. The fracture of the spring occurred on the middle coil having the largest diameter.

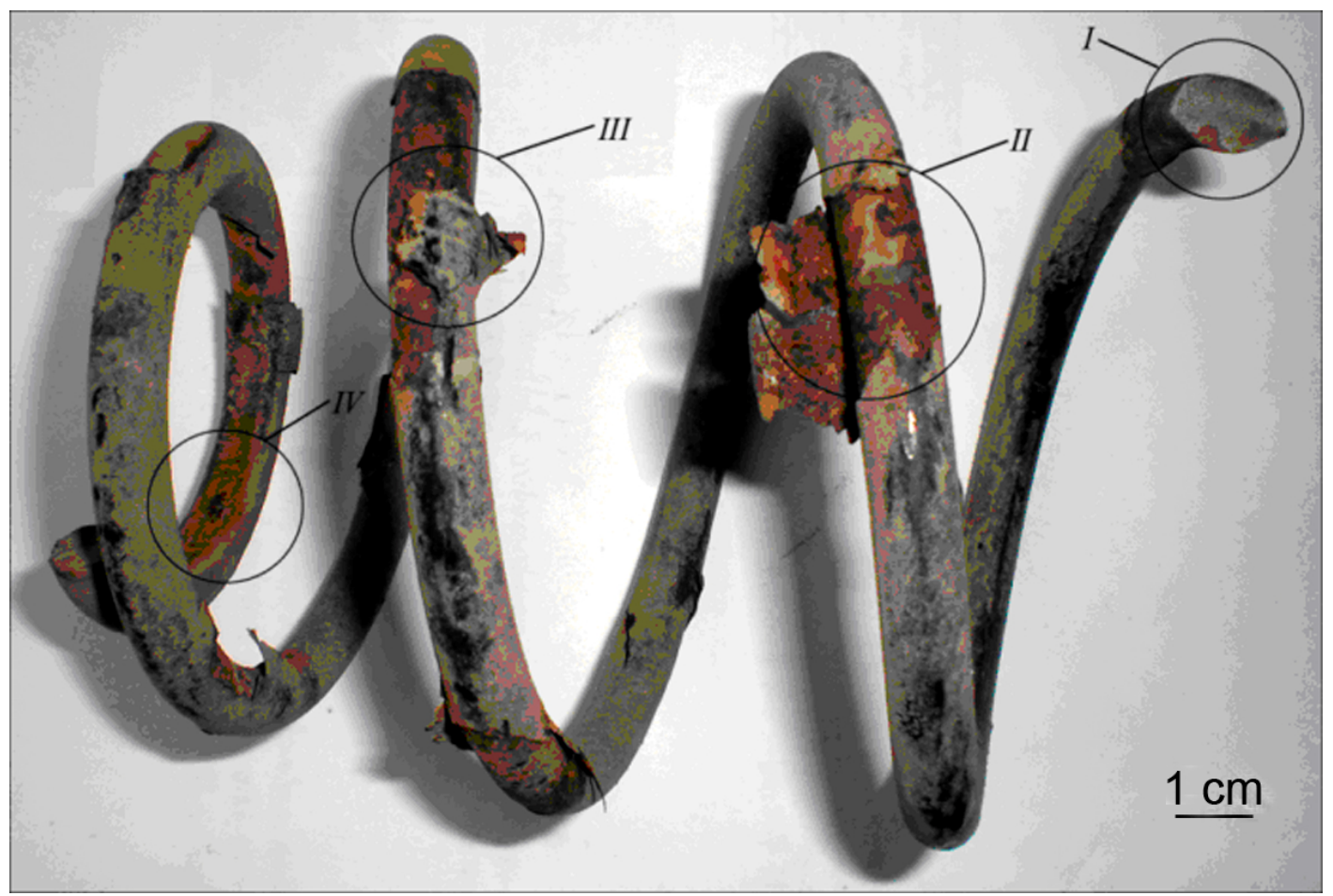

a

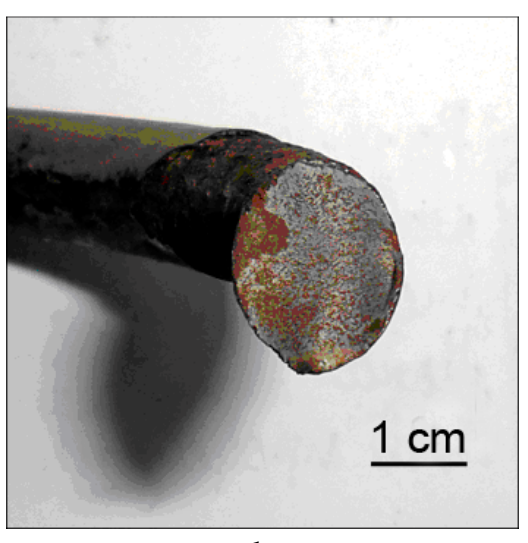

b

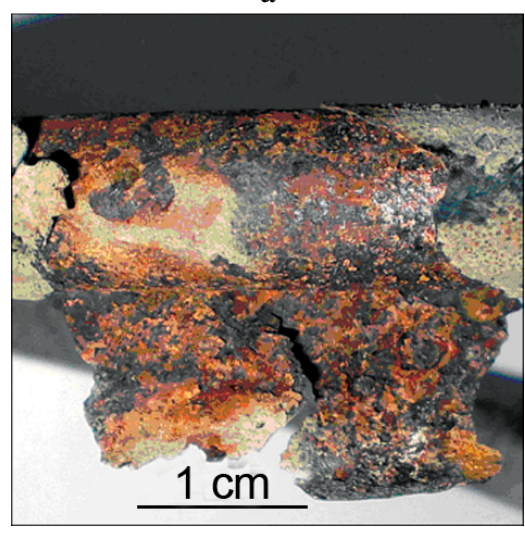

$\mathrm{c}$

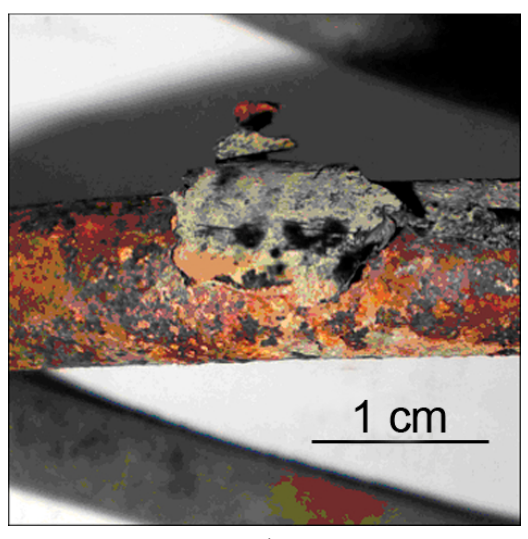

d

Fig. 1. The appearance of the spring of the rear suspension of the Ford Fiesta car: $a$ - general view; $b$ - fragment I; $\mathrm{c}$ - fragment II; d - fragment III 
The quality of the spring was checked visually with a magnifying glass with 5 times magnification in accordance with DSTU 8429:2015 [15]. The appearance of the spring and the fracture was documented using a Casio Exilim 8.1 Mega Pixels camera (Fig. 1, $a, b$ ). During the inspection, no cracks, hairlines, rolled-in scales, electric burns, small dents, scratches, marks of spring coiling tool, and the remains of lubricants were observed on the surface of the spring. Instead, traces of rust and erosion of the protective coating were observed, which led to its exfoliation from the spring surface (Fig. 1, $c, d$ ).

For the subsequent researches, three samples of $20-30 \mathrm{~mm}$ in length were taken from places of the main damages (Table 1). Samples were cut off with acceptable heating of steel, which did not cause structural changes in it.

Table 1

\section{Protocol for sampling and marking of samples for investigation}

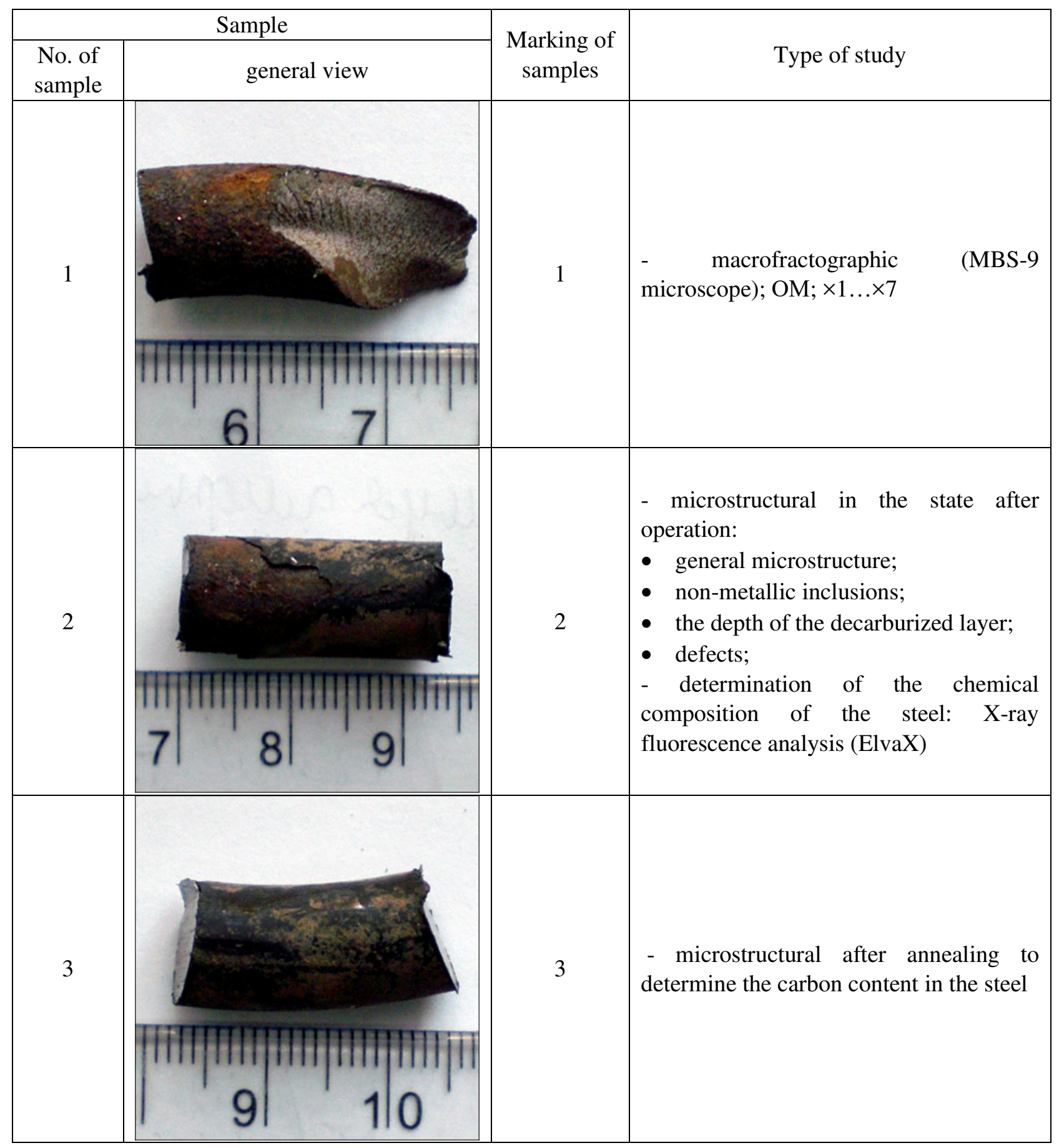




\section{Lidia Bohun, Eduard Pleshakov, Sergiy Shvachko}

Macrofractographic studies of the fracture surface were performed using an MBS- 9 microscope at magnifications of up to 7 times. The fatigue crack propagates from the fracture origin (Fig. 2, $a$, indicated by an arrow) with the reorientation of the crack plane along the spiral surface to the central axis of the coil wire (see Table 1, sample 1). The zone of the steady fatigue crack propagation is smoothed and identified by fatigue ridges - traces of movement of the crack front, which diverge concentrically from the crack initiation point (Fig. 2, $a, b$ ). After depletion of the safety margin, the spring broke down quickly. The fast fracture zone with a transverse size of about $6 \mathrm{~mm}$ contains steps of the river pattern formed due to the spiral reorientation of the fracture surface (Fig. 2, $c, d$ ).

Microstructural studies (DSTU ISO 4967:2017) were performed on non-etched and etched with 4\% nitric acid solution microsections using an MMT-14C optical microscope at magnifications of 100 to 500 times.

Evaluation of non-metallic inclusions in steel springs was performed according to DSTU ISO 4967:2017 (GOST 1778) [16]. A small number of dot particles of oxides (Fig. 3) and single elongated sulfides, which are usually double sulfides of iron and manganese, were found. Oxide and sulfide inclusions in their maximum size are twice smaller than the inclusions that correspond to the grade 1 of the reference scales, so they are evaluated by the grade 0 .

Car springs are made of rolled products, for which dot inhomogeneity, central porosity, and liquation square should not exceed the grade 2 [15]. Therefore, the quality of spring rolling on non-metallic inclusions meets the requirements for the rolling for the manufacture of car springs.

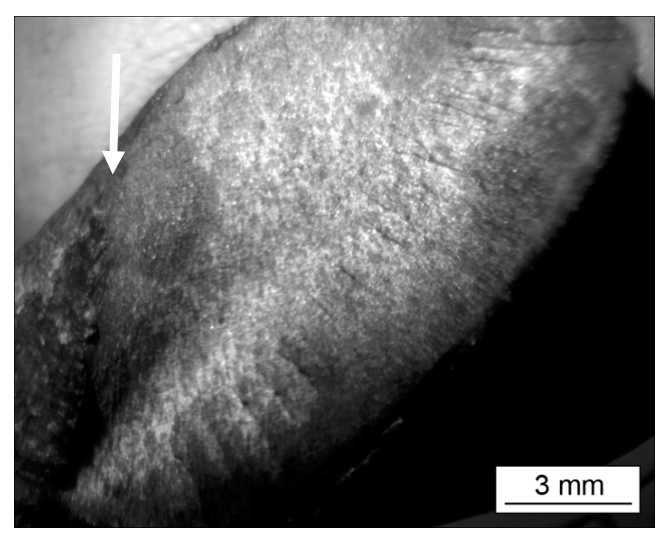

a

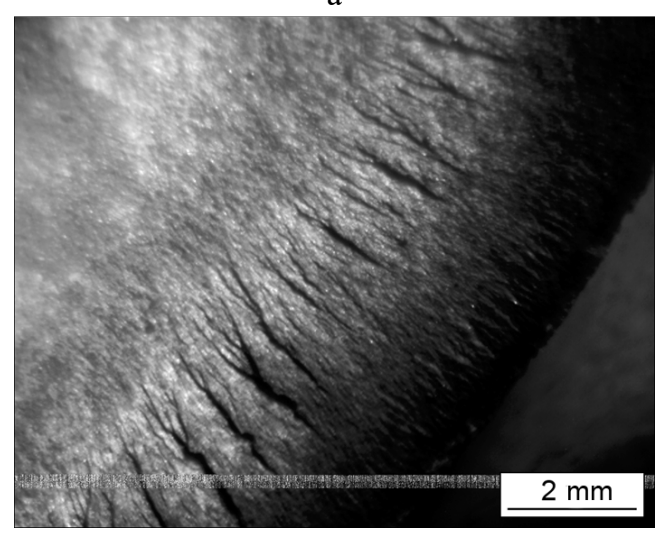

c

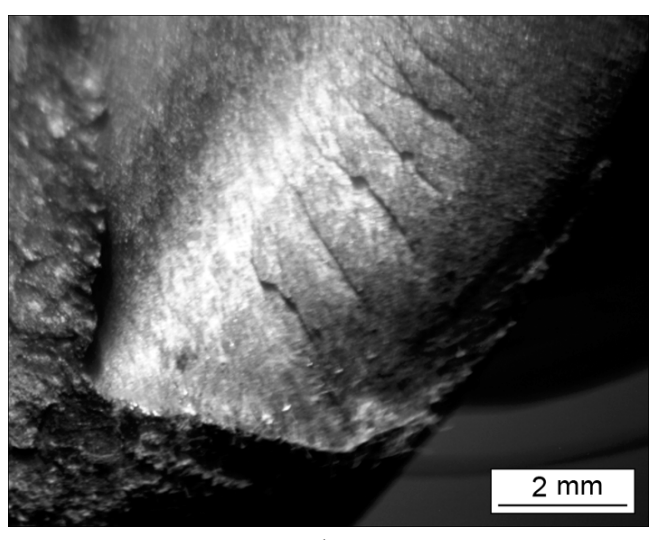

b

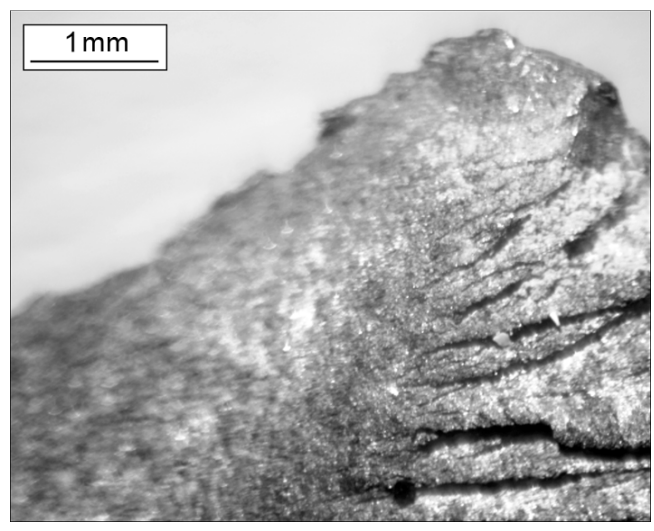

d

Fig. 2. Macrostructures of the zones of the spring fracture surface: (a) the crack origin (indicated by an arrow); (b) transition from the fracture origin to the fatigue crack propagation zone; (c) the fatigue crack propagation zone; (d) the fast fracture zone

The depth of the decarburized layer was determined by the metallographic method $\mathrm{M}$ [17] on the transverse sections (see Table 1, sample 2) contrasted in $4 \%$ alcohol solution of nitric acid, at magnifications of $65-100$ times. 


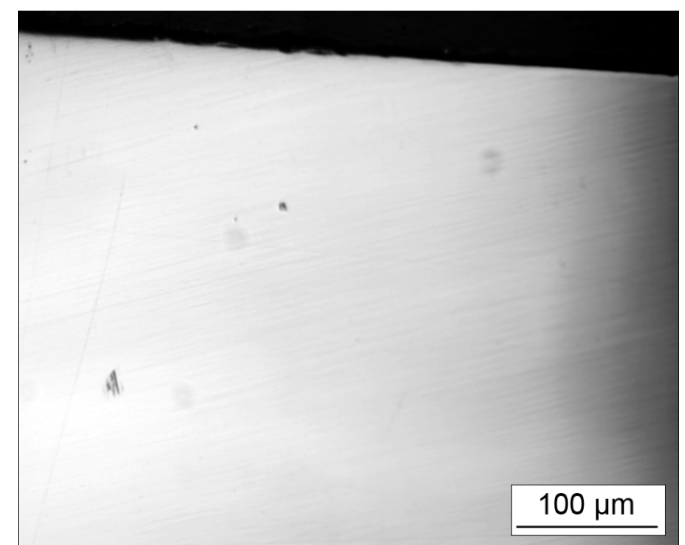

a

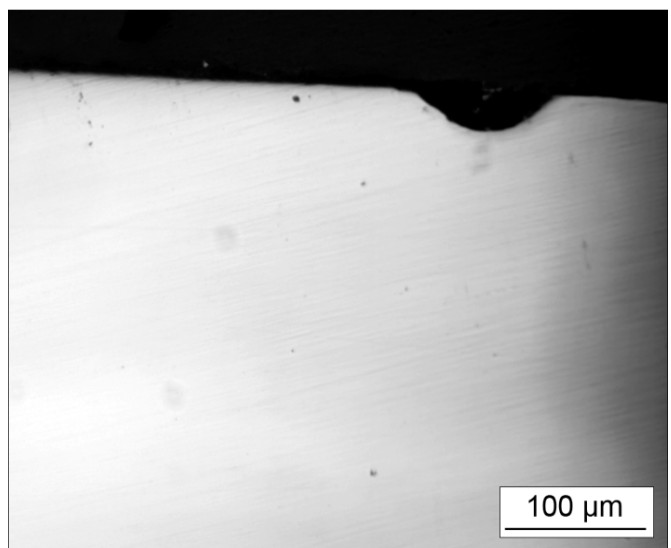

b

Fig. 3. Microstructures of non-etched microsections (see Table 1, sample 1)

For a spring with a wire diameter of more than $8 \mathrm{~mm}$, made of rolled products, according to the standards [15], the one-side depth of the decarburized layer cannot exceed $2 \%$ of the allowable depth of the decarburization in total.

Microstructural study of the spring after operation, having a structure of troostite of tempering, found no traces of decarburization, even at the recommended allowable magnification of 500 times (Fig. 4).

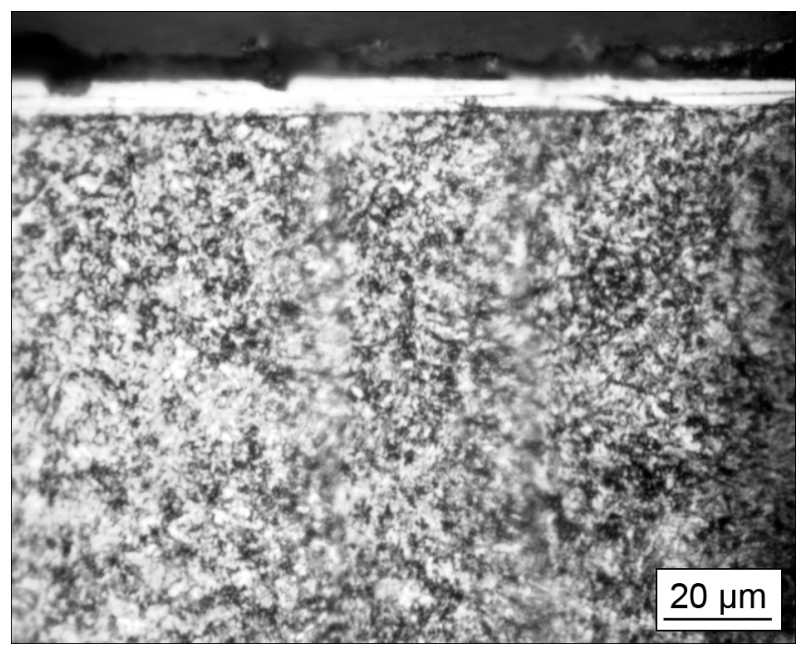

Fig. 4. Microstructure of the spring of the Ford Fiesta car after heat treatment and application of a protective surface coating (after operation)

The standard recommends for steels with a structure in which it is difficult to detect the decarburized layer, to carry out additional heat treatment - normalizing or annealing in conditions that exclude decarburization or carburization. In order to clarify the structural features of decarburization, sample 3 (Table 1) was annealed, and its microstructure was examined after etching. No traces of decarburization were detected. Therefore, the quality of the spring on the decarburization meets the requirements of the standard.

Springs according to DSTU GOST 13766:2008 [18] are strengthened by heat treatment (hardening at $870^{\circ} \mathrm{C}$ with cooling in oil and tempering at $470^{\circ} \mathrm{C}$ ) with subsequent shot peening. After such treatment, their hardness should be 47.5-53.5 HRC with a deviation of \pm 4 units. Then the springs are loaded at least 3 times to the touch of the adjacent coils or to the certain height. Permissible deviation of the stiffness from nominal is $\pm 3 \%$. Springs with a wire diameter of more than $8 \mathrm{~mm}$ are coiled in a heated state. The average hardness of the investigated spring, measured by the Vickers method [19], was $580 \mathrm{HV}$, which completely meets the requirements for the manufacture of springs according to [18]. The ultimate tensile strength of steel, calculated from the value of hardness according to [20], is: $R_{\mathrm{m}}=3.2 \cdot \mathrm{HV}=1856 \mathrm{MPa}$. 


\section{Lidia Bohun, Eduard Pleshakov, Sergiy Shvachko}

The chemical composition of the steel of the rear suspension spring of the Ford Fiesta car was determined by X-ray fluorescence spectral analysis using an ElvaX device [21]. The results are presented in Table 2.

Table 2

Chemical composition of the steel of the rear suspension spring of the Ford Fiesta car

\begin{tabular}{|c|c|c|c|}
\hline Atomic number & Element & Intensity & Element concentration, $\%$ \\
\hline 26 & $\mathrm{Fe}$ & 1668603 & $97.5076 \pm 0.0312$ \\
\hline 14 & $\mathrm{Si}$ & 8404 & $1.1603 \pm 0.0225$ \\
\hline 25 & $\mathrm{Mn}$ & 9421 & $0.6967 \pm 0.0321$ \\
\hline 24 & $\mathrm{Cr}$ & 14028 & $0.6495 \pm 0.0303$ \\
\hline 15 & $\mathrm{P}$ & 3715 & $0.0222 \pm 0.0168$ \\
\hline 13 & $\mathrm{Al}$ & 301 & $0.0972 \pm 0.0398$ \\
\hline 28 & $\mathrm{Ni}$ & 100 & $0.0143 \pm 0.0213$ \\
\hline 16 & $\mathrm{~S}$ & 737 & $0.0127 \pm 0.0045$ \\
\hline
\end{tabular}

Since the device does not determine the content of light elements (up to atomic number $Z=11$ ), the carbon content was determined metallographically by the structure in the annealed (equilibrium) state (Fig. 5). An approximate estimate of the carbon content in the spring steel was performed according to the standard DSTU 7175:2010 [22]. By comparing the equilibrium microstructure of the spring (Fig. 5) with scales of the standard, it is established that the microstructure corresponds to grades $3-4$ on the scale 7 . This indicates the content of pearlite in the structure of steel $70-80 \%$, and ferrite $-30-20 \%$. Thus, the approximate carbon content in the steel is 0.56 to $0.64 \%$.

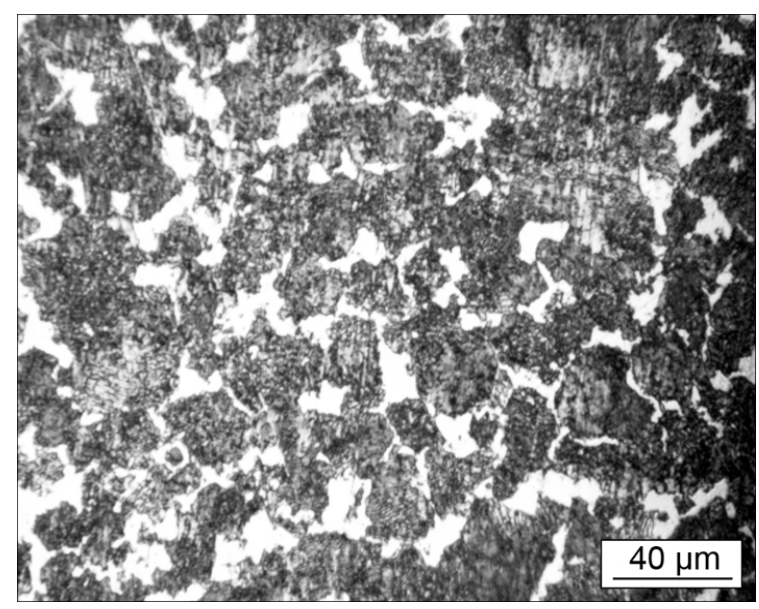

Fig. 5. Microstructure of the spring steel after annealing

The refinement of the carbon content in the steel structure was performed using a software product for image processing analysis ImageJ [23]. The images obtained by optical microscopy were processed to accurately determine the area of the dark component of the structure - pearlite. The determined amount of pearlite was $82 \%$, which corresponds to the carbon content in the steel of $0.63 \%$. In this way, the approximate chemical composition of the spring steel has been established (Table 3).

The Ford company uses suspension springs made of the 54SiCr6 spring steel (DIN EN 10089:2003 [24]) by H\&R company [25] in Ford Fiesta cars. The closest domestic analog of this steel is spring steel of the 60C2A grade in accordance with DSTU 8429:2015 [15]. The chemical composition and mechanical properties of these steels in comparison with the steel of the investigated spring are presented in Tables 3 and 4 , respectively.

Chromium in these steels increases the strength limit, hardness, hardenability, wear resistance, and corrosion resistance. Silicon, which is used to deoxidize steels, has a similar but weaker effect on these 
mechanical properties [26]. Decarburization, which can be caused by silicon, is prevented by reducing its content in steel to $1.2 \%$ and adding chromium.

Table 3

Comparison of the chemical composition of the steel of the investigated spring and its analogs used for manufacturing springs [15, 24]

\begin{tabular}{|c|c|c|c|c|c|c|c|}
\hline \multirow{2}{*}{ Steel grade } & \multirow{2}{*}{ Standard } & \multicolumn{6}{|c|}{ Chemical composition, \% } \\
\cline { 3 - 8 } & - & $\mathrm{C}$ & $\mathrm{Si}$ & $\mathrm{Mn}$ & $\mathrm{Cr}$ & $\mathrm{P}$ & $\mathrm{S}$ \\
\hline Sample 1 & - & 0.63 & 1.16 & 0.69 & 0.65 & 0.022 & 0.013 \\
\hline 54SiCr6 & $\begin{array}{c}\text { DIN EN } \\
10089-2003\end{array}$ & $0.51-0.59$ & $1.2-1.6$ & $0.5-0.8$ & $0.5-0.8$ & 0.025 & 0.025 \\
\hline 60C2A & DSTU 8429:2015 & $0.58-0.63$ & $1.6-2$ & $0.6-0.9$ & 0.3 & 0.025 & 0.025 \\
\hline
\end{tabular}

To protect the springs from premature failure under the influence of the atmospheric environment, they are covered with a special protective coating. The protective layer must be dense, non-porous, and must not impair the mechanical properties of the springs. Metal electrolytic coatings (chromium, nickel, cadmium, zinc, etc.) and chemical ones (oxidation, phosphating) are the most common types of coatings for corrosion protection of springs.

Mechanical properties of the steels used for manufacturing springs [15, 24]

\begin{tabular}{|c|c|c|}
\hline Steel grade & $R_{\mathrm{m}}(\mathrm{MPa})$ & HRC \\
\hline Sample 1 & 1856 & 49.2 \\
\hline 54SiCr6 & $1450-1750$ & $44.5-50$ \\
\hline 60C2A & 1900 & $44.5-63$ \\
\hline
\end{tabular}

Many car spring manufacturers use zinc phosphating, which provides good adhesion to the paint layer, for corrosion protection. To protect against mechanical damage, stone and rubble impacts, a thicker layer (for example, powder epoxy coating), which absorbs the impact energy, is formed above the corrosion-resistant layer.

Microstructural studies of the spring showed that a protective coating was applied to its surface (Fig. 4). The thickness of the spring coating, which was determined by the results of three measurements, ranged from 6 to $7 \mu \mathrm{m}$.

The results of X-ray fluorescence spectral analysis of the exfoliated piece of coating are presented in Table 5 .

Table 5

Chemical composition of the protective coating on the investigated spring

\begin{tabular}{|c|c|c|c|}
\hline Atomic number & Element & Intensity & Element concentration, \% \\
\hline 56 & $\mathrm{Ba}$ & 115621 & $77.6630 \pm 0.3820$ \\
\hline 26 & $\mathrm{Fe}$ & 1029018 & $10.0422 \pm 0.0498$ \\
\hline 20 & $\mathrm{Ca}$ & 186826 & $5.8198 \pm 0.0396$ \\
\hline 14 & $\mathrm{Si}$ & 37050 & $4.1096 \pm 0.0556$ \\
\hline 13 & $\mathrm{Al}$ & 2874 & $1.0840 \pm 0.0800$ \\
\hline 16 & $\mathrm{~S}$ & 39574 & $0.9175 \pm 0.0134$ \\
\hline 15 & $\mathrm{P}$ & 3592 & $0.3176 \pm 0.0323$ \\
\hline 38 & $\mathrm{Sr}$ & 37947 & $0.0335 \pm 0.0005$ \\
\hline 30 & $\mathrm{Zn}$ & 2005 & $0.0054 \pm 0.0004$ \\
\hline 24 & $\mathrm{Cr}$ & 227 & $0.0036 \pm 0.0069$ \\
\hline 29 & $\mathrm{Cu}$ & 655 & $0.0028 \pm 0.0005$ \\
\hline 33 & $\mathrm{As}$ & 647 & $0.0010 \pm 0.0003$ \\
\hline
\end{tabular}


For suspension springs produced by H\&R company in Germany [25], which are made of the 54SiCr6 spring steel, protective polymer coatings are used. They are formed on the surface of a spring by vortex spraying of powdery polymer compositions. Unfortunately, according to the chemical composition determined by X-ray fluorescence analysis (Table 5), it is quite difficult to determine the composition of the powder material of the polymers that were used to form the protective coating on the investigated spring. In the Ukrainian industry, a protective coating for such springs is usually formed in several layers: a phosphatized layer, a primer layer, and two layers of varnish.

Visual assessment of the coating according to DSTU 3830-98 [27] and microstructural studies of the surface layer of the spring after operation revealed corrosion damage in places of exfoliation of the protective coating (Figs. 1 and 6). External inspection of the spring after operation showed that the coating was exfoliated on large surfaces (Fig. 1). The metallographic analysis revealed non-uniform selective corrosion, which causes exfoliation of the protective coating and spreads to the depth of the product in the form of pitting damage (Fig. 6). One of such deep pits became the initiation site of the main fatigue crack in the spring.

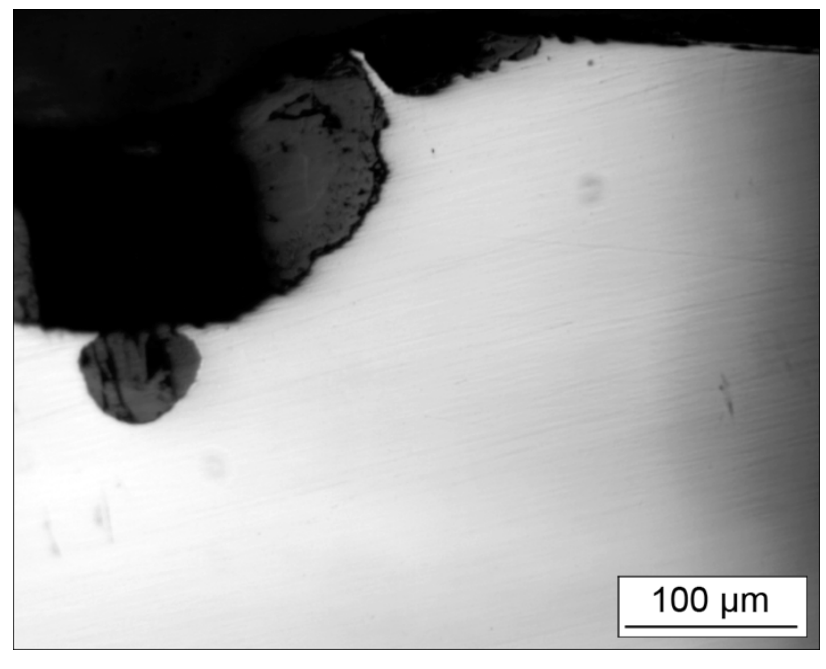

a

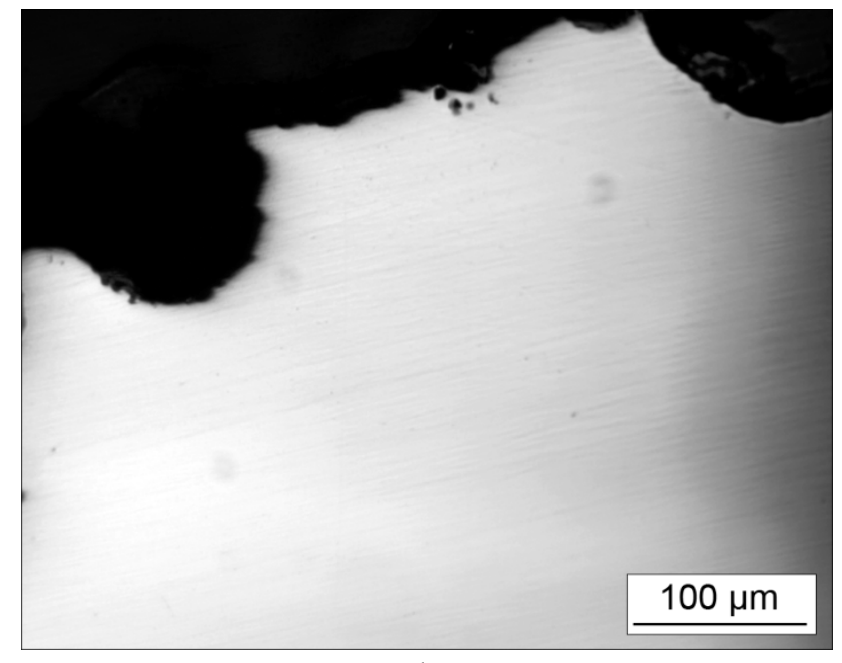

b

Fig. 6. Microstructure of corrosion damage to the spring surface in places of exfoliation of the protective coating

\section{Conclusions}

The research conducted in this work was aimed at identifying the cause of the failure of the motor vehicle rear suspension spring. No technological or operational damages, such as cracks, dents, scratches, traces of the tool, were observed on the surface of the spring. The structure and mechanical properties of the spring material meet the standards. No crack initiation, caused by non-metallic inclusions, was found in the material of the fractured spring.

Instead, extensive exfoliation of the protective coating was found. Local corrosion damage in the form of deep pits, which formed in unprotected areas under the influence of operational factors, caused fatigue fracture of the middle coil of the barrel-shaped spring, which operates under conditions of more severe stress in comparison with other coils. The analysis of deformation fields performed in the work [28] confirms the fact that in progressive springs, the central coils are most deformed in contrast to linear cylindrical springs, in which the deformation of coils is the same.

Thus, the cause of the failure of the rear suspension spring of the car was the corrosion fatigue of the material due to the simultaneous action of the corrosive environment and cyclic alternate loading.

The research can be used to understand the importance of adhesive strength and wear resistance of protective coatings on the spring surface. Their local exfoliation causes subsequent corrosion damage to the spring, which stimulates its fatigue fracture. 


\section{Failure Analysis of a Motor Vehicle Suspension Helical Spring}

\section{References}

[1] O.A. Fenenko, "Defekty prujin podveski transportnogo sredstva i protsessy, privodyaschie k nim" ["Defects in vehicle suspension springs and processes leading to them"], Visnyk Kharkivs'koho natsional'noho tekhnichnoho universytetu sil's'koho hospodarstva imeni Petra Vasylenka [Bulletin of the Petro Vasylenko Kharkiv National Technical University of Agriculture], vol. 167, pp. 92-99, 2016. [in Russian].

[2] O.A. Fenenko, and M.A. Oksentyuk, "Vliyanie vneshnih faktorov na prosadku prujin podveski transportnogo sredstva" ["The influence of external factors on the subsidence of the vehicle suspension springs"], Zbirnyk naukovykh prats Kharkivskoho natsionalnoho universytetu povitrianykh syl [Collected scientific works of Kharkiv National Air Force University], vol. 52, issue 3, pp. 118-120, 2017. [in Russian].

[3] Y. Prawoto, et al., "Design and failure modes of automotive suspension springs", Engineering Failure Analysis, vol. 15, pp. 1155-1174, 2008.

[4] Y. Chaubey, C. Kumar, and S. Chauban., "Failure analysis of suspension coil spring for passenger car through SEM microstructure investigation", International Journal of Innovations in Engineering and Technology, vol. 7, issue 1, pp. 82-87, June 2016.

[5] M.A. Yar, et al., "Corrosion behaviour of an industrial shot-peened and coated automotive spring steel AISI 9254", Corrosion Engineering, Science and Technology, vol. 53, no. 8, pp. 564-573, 2018.

[6] M.F. Berejnitskaya, "Vliyanie ostatochnyh napryajeniy na soprotivlyaemost stali korrozionnomehanicheskomu razrusheniyu" ["The influence of residual stresses on the resistance of steel to corrosion-mechanical fracture"], Fiziko-Khimicheskaya Mekhanika Materialov [Physicochemical Mechanics of Materials], vol. 23, no. 1, pp. 22-26, Feb. 1987. [in Russian].

[7] Y. Harada, et al., "Effect of microshot peening on fatigue life of spring steel SUP9", Procedia Engineering, vol. 81, pp. 1493-1498, 2014.

[8] Y. Mahajan, A. Y. Vyavahare, and D. R. Peshwe, "Failure analysis of tension spring", International Journal of Engineering Research and Technology, vol. 3, issue 5, pp. 953-956, 2014.

[9] M.T. Todinow, "Internal reports on the project high-strength steels for automotive suspension spring", School of Metallurgy and Materials, The University of Birmingham, Birmingham, United Kingdom, Nov. 1994.

[10] Y. Zhu, Y. Wang, and Y. Huang, "Failure analysis of a helical compression spring for a heavy vehicle's suspension system", Case Studies in Engineering Failure Analysis, vol. 2, pp. 169-173, 2014.

[11] G. Vukelic, and M. Brcic, "Failure analysis of a motor vehicle coil spring", Procedia Structural Integrity, vol. 2, pp. 2944-2950, 2016.

[12] L. Kosec, et al., "Failure analysis of a motor-car coil spring", Case Studies in Engineering Failure Analysis, vol. 4, pp. 100-103, 2015.

[13] R. Fragoudakis, et al., "The effect of heat and surface treatment on the fatigue behaviour of $56 \mathrm{SiCr} 7$ spring steel”, Procedia Engineering, vol. 74, pp. 309-312, 2014.

[14] Pruzhyny. Terminy ta vyznachennia [Springs. Terms and definitions], DSTU 2262-93, 1994. [in Ukrainian].

[15] Prokat iz resorno-pruzhynnoi vuhletsevoi ta lehovanoi stali. Tekhnichni umovy [Rolled spring-loaded carbon and alloyed steels. Specifications], DSTU 8429:2015, 2016. [in Ukrainian].

[16] Stal. Vyznachennia vmistu nemetalevykh vkliuchen. Metalohrafichnyi metod otsiniuvannia za standartnymy shkalamy (ISO 4967:2013, IDT) [Steel. Determination of the content of non-metallic inclusions. Metallographic method of evaluation on standard scales (ISO 4967:2013, IDT)], DSTU ISO 4967:2017, 2017. [in Ukrainian].

[17] Stal. Vyznachannia hlybyny znevuhletsiuvannia (ISO 3887:2003, IDT) [Steel. Determining the depth of decarburization (ISO 3887:2003, IDT)], DSTU ISO 3887:2009, 2016. [in Ukrainian].

[18] Tekhnichna dokumentatsiia na produktsiiu. Pruzhyny. Chastyna 2. Podannia danykh dlia tsylindrychnykh spiralnykh pruzhyn stysnennia [Technical documentation for products. Springs. Part 2. Data representation for cylindrical helical compression springs], DSTU EN ISO 2162-2:2018 (EN ISO 2162-2:1996, IDT; ISO 2162-2:1993, IDT), 2019. [in Ukrainian].

[19] Materialy metalevi. Vyznachennia tverdosti za Vikkersom. Chastyna 1. Metod vyprobuvannia [Metallic materials. Determination of Vickers hardness. Part 1. Test method], DSTU ISO 6507-1:2007, 2010. [In Ukrainian].

[20] H. E. Boyer, and T. L. Gall, Metals Handbook. Materials Park, OH, USA: American Society for Materials Publ., 1985.

[21] Elvatech: Advanced XRF equipment and solutions. [Online]. Available: https://elvatech.com. Accessed 


\section{Lidia Bohun, Eduard Pleshakov, Sergiy Shvachko}

on: July 30, 2020.

[22] Metaly ta splavy. Metody metalohrafichnoho kontroliuvannia. Terminy ta vyznachennia poniat' [Metals and alloys. Methods of metallographic control. Terms and definitions], DSTU 7175:2010, 2011. [in Ukrainian].

[23] Purdue University Cytometry Laboratories. [Online]. Available: www.cyto.purdue.edu. Accessed on: July $30,2020$.

[24] Hariachekatani stali dlia vidpushchenykh i zahartovanykh pruzhyn - Tekhnichni umovy postavky [Hotrolled steels for tempered and hardened springs - Delivery specifications], DIN EN 10089:2003, 2003. [in Ukrainian].

[25] H\&R Company profile. [Online]. Available: https://www.h-r.com/en/company-profile/. Accessed on: July $30,2020$.

[26] J. Gordine, and I. Codd, "The influence of Si up to $1.5 \mathrm{wt} \%$ on the tempering of a spring steel", Journal of the Iron and Steel Institute, vol. 207, issue 1, pp. 461-467, 1969.

[27] Koroziia metaliv $i$ splaviv. Terminy ta vyznachennia osnovnykh poniat' [Corrosion of metals and alloys. Terms and definitions of basic concepts], DSTU 3830-98, 1999. [in Ukrainian].

[28] A. Yu. Bajanova, "Sravnitelnyi analiz napryajeno-deformirovannogo sostoyaniya prujin s lineynoy i progressivnoy uprugimi harakteristikami" ["Comparative analysis of the stress-strain state of springs with linear and progressive elastic characteristics"], Visnyk Kyivs'koho natsional'noho universytetu tekhnolohiy ta dyzaynu [Bulletin of the Kyiv National University of Technologies and Design], vol. 80, no. 6, pp. 18-24, 2014. [in Russian]. 